\title{
Violating Politeness Principle Of Cucuk Lampah For Creating Humor In Wedding Ceremonial In Magetan Regency
}

\author{
${ }^{1}$ Qoniatul Mubarokah, ${ }^{2}$ Djatmika, ${ }^{3}$ Sumarlam \\ ${ }^{1,2,3}$ Sebelas Maret University, Surakarta \\ \{qonia.mubarokah@gmail.com¹, djatmika@staff.uns.ac.id², sumarlamwd@gmail.com³
}

\begin{abstract}
Cucuk Lampah is leader of procession called kirab pengantin that moves towards stage (pelaminan) in wedding ceremonial Javanese tradition. Cucuk Lampah in Magetan has an ability to do humor by developing certain topics and uses pragmatic aspect which can not be separated from violating politeness principle. This study is purposed to identify interpersonal meaning in creating humor Cucuk Lampah in wedding ceremonial in Magetan. The researcher uses pragmatic approach. The data of this research is oral data delivered by Cucuk Lampah. The collected data uses simak method. It uses pragmatic method based on utterances by heuristic technique to analyze data. The result shows that in creating humor, Cucuk Lampah uses violating politeness principle to build up setup and punch. Based on 44 data of Cucuk Lampah utterances, the percentages are: Tact maxim 37\%, Generosity maxim $9 \%$, Approbation maxim 23\%, Modesty maxim 2\%, Agreement maxim 27\%, and Sympathy maxim $2 \%$.
\end{abstract}

Keywords: Humor, Politeness principle, Cucuk lampah

\section{INTRODUCTION}

The using of language play in communication can reveal laughter and impression of being relaxed with the participants of the speech events. This inidicates that speaker has ability to work definitions of humor for making comfortable in speech events. According to Soedjatmika (1992: 69) Humor is one of means communication such as giving information, expressing happiness, anger, annoying, and sympathy. In life, humor is closely related to social behavior community. Wijana (2004: xx) mentioned that humor is one form of play, and verbal and visual stimulation that is spontaneously intented to provoke smile and laugh from hearer or person who see it.

Furthermore Widjaja (1993:98) concluded that joke or humor occurred for normal humans, to entertain because of entertainment is absolute necessity for humans to endure themselves in defense process their life. Concept of humor divided into three main theories named Incongruity theory, Conflict theory, and Relief theory (Wijana, 2004: 21). Incongruity theory explained that humor in a manner incongruity integrats two different meaning or interpretation 
which different in a complex object. Parts of that incongruity is perceived suddenly by its hearer. Humor stands on the theory which is based on the concept about conflict and incongruity with violating of pragmatic rules in using language.

Leech (in Sumarlam, 2017 : 181-187) divided politeness priniciple such as (1) Tact maxim, (2) Generosity maxim, (3)Approbation maxim, (4) Modesty maxim, (5) Agreement maxim, (6) Sympathy maxim. Humor has formed in several of discourse, both oral and written discourse. One of humor in oral discourse is Cucuk Lampah humor in wedding ceremonial in Magetan regency. Humor of Cucuk Lampah is dialogue form that is done with Pambiwara, singers, guests, manggala or domas etc. Cucuk Lampah humor takes place during the Ksatrian procession after coming down from stage (pelaminan)

Cucuk Lampah procession of javanese tradition wedding ceremony as an opening way has intented the repellent procession to chase away all of interference in any kinds of forms, especially spirit evil that can disturb the way of wedding ceremony. There is a procession called kirab pengantin, namely kirab Kanarendran and kirab Kesatriyan in this procession. In kirab Kanarendran, Cucuk Lampah acts as the leader of the procession and moves towards the stage (pelaminan) and leave the room for changing their clothes for the next kirab namely kirab Ksatrian.

Cucuk Lampah as a guide to convoy kirab procession which has followed by dancing movements. However, in Magetan regency, Cucuk Lampah has delivered humor about local people in life. One of them is moral value that is packaged in humor and also ridiculus to achieve certain goals.

Related with explanation above, there are some previous studies which examine the subject about humor or wedding ceremony. It can be used as literature review such as: The first, research of Cucuk Lampah by Dwiyasmono (2009) entitled "Subamanggala in Wedding Ceremonial Rites from Surakarta: a Reflection on Leadership from a Cultural Perspective". In his research, Dwiyasmono described the meaning and role of Cucuk Lampah in cultural perspective through dance movements, symbols, behavior movements which represents the value in people live. Furthermore, in this research, it was not yet in language domain of Cucuk Lampah which was studied.

The second, the research about Coherence that was done by Mulyana (2001) entitled: "Structures, Esthetics, and Changes of Contexts in Discourse Speech Wedding Ceremonies Conducted by Javanese people". The researcher described the forms of lingual markers which had a role to help the types of coherence relationship between coheren parts and coherence patterns in Sesorah marriage. However, the research has different data sources and the utterances is monologue.

To achieve humor utterances, Cucuk Lampah reveals violating in language usage. Wijana and Rohmadi (2009: 139) argued that humor discourse is often done by violating politeness principle, that discourse clearly does not heed politeness rules or just pretend to be polite. But, actually impoliteness is one of manifestations of reciprocal interference as the main way in creating humor. Speech act of language play in violating politeness principle in creating humor is an interesting phenomenon to be investigated. Doing violation of politeness principle does not make effective communication. Based on problem, the research question as follows: How are the implementation of violating politeness principle Cucuk Lampah for Creating Humor in Wedding Ceremonial in Magetan Regency? 


\section{METHODOLOGY}

This research uses descriptive qualitative method. The place was choosen as well as target research namely in Magetan regency. This research was begun with the data collection extracted from oral that delivered by Cucuk Lampah in dialogue with Pambiwara, guests, singer, manggala or domas etc in wedding ceremony. According to linguistic perspective, solving the problem in research is required into three stages, such as (1) collecting the data, (2) analyzing data, (3) data presentation. To do all the stages, methods and techniques are needed for each stage (Sudaryanto, 2015: 5-8)

The method of collecting data conducted by simak method with basic technique used sadap technique, then (1) SBLC technique through listening that was used by Cucuk Lampah in wedding ceremony. (2) Note technique, and video recording technique. In data analysis, after reading all the script data that were transcribed to understand the context of situation, then made classification. This analysis data used pragmatig method based on Cucuk Lampah utterances with heuristic analysis technique. The analysis was focused based on utterances that contained politeness theory by Leech. Finally, data were presented with informal and formal method.

\section{FINDING AND DISCUSSION}

Based on data that were gained, collecting data was based on utterances which contained violating politeness principle, as follow:

a. Violating of Tact Maxim

Datum 18 (00:04:04-00:04:24)

Context : Domas wear hijab during wedding ceremoniy as request from a host to the make-up. Then, Cucuk Lampah asks to Domas for dancing.

Cucuk Lampah : Semuanya bergoyang (Everybody's rocking)

Pambiwara : Oke

Cucuk Lampah : Oke

Pambiwara : Oke

Cucuk Lampah : Ready ready siap siap. Kene- kene gak sakit. Joget gak sakit Omongono Wik, omongono. Joget gak sakit Wik

(Ready ready ready ready. Here, it does not hurt. Dancing does not hurt. Tell to them Wik, just saying. Dancing does not hurt Wik)

Dewi (Singer) : Oh ya, he pasukan joget siap grak

Cucuk Lampah : Oke

(Oh yes, dancing troops attention)

Dewi (Singer) : Gak usah dipegangin sayang. Ora-ora

Cucuk Lampah : Joget joget

(It does not hold sayang. It's okay)

Dewi : Ora-ora, iki ki ora nggragas

(It's okay, he is not greedy)

In utterance datum 18, Cucuk Lampah maximizes the loss for Domas who are asked to dance with song accompaniment from Sri Huning Mustiko Tuban. Wearing closed clothes, Domas fell shy when starting to move slowly because they dance in front of the guest 
invitation. That matter is shown through the utterances "everybody's rocking" which is directed to Domas. Cucuk Lampah convinces back by asking the help to Dewi "Ready ready ready ready. Here, it does not hurt. Dancing does not hurt. Tell to them Wik, just saying. Dancing does not hurt" to force all the Domas of about four. He repeats again for the invitation to dance up to three times utterances.

\author{
Datum 33 (00:11:06-00:11:16) \\ Context : Cucuk Lampah takes the Kenong player's ice without permission. Then, it \\ is given to Domas as a sign of appreciation for dancing. \\ Cucuk Lampah : Patut dikasih hadiah \\ (It is served gift) \\ Pambiwara : Sek, hadiahe opo? \\ (Wait,what's a gift?) \\ Cucuk Lampah : Nah iki digowo sek. Hee mrono \\ (Well, this is taken first. Hey over there) \\ Pambiwara : Mriko mriko. Sek iki jatahe kene kok mbok gowo mrono \\ (Overthere, overthere. Wait, this is for us how come you bring it overthere)
}

The utterance "Well, this is taken first. Hey overthere" shows that Cucuk Lampah does violating of tact maxim towards Kenong player. Without permission, Cucuk Lampah immediately takes the ice. Then, it is given to Domas as a gift for dancing. The word "this" refers to ice. Pambiwara immediately replies the statement "This is for us how come you bring it”, but Cucuk Lampah ignores him.

\title{
b. Violanting of Generosity maxim
}

Datum 3 (00:00:51-00:01:01)

Context : The host gives a packet of Surya cigarette, so that Cucuk Lampah shows the performance that makes the guest invitation feeling happy toward his performance.

Cucuk Lampah : Halah de,halah repot'e. ndadak ngaggo surya barang. Aku malah watuk

(Halah de, halah just bother. Suddenly uses Surya. I am even cough) Pambiwara : Halah, padhimu nek ora diwehi ngrasani. Modelmu

(Halah, you would like if it is not given. Talk about other people's ugliness)

That conversation is informal when humor is presented by Cucuk Lampah. it has become commonly for local society, cigarettes are an item that is always served in celebrating like wedding ceremonial as a treat. "Surya" in his utterance means cigarretes which is brand "Surya". The utterance of Cucuk Lampah "Halah de, halah just bother. Suddenly uses Surya. I am even cough" shows his benefit after getting one pack of cigarette. Cucuk Lampah speaks small talk or reluctant for the giving, but actually he expects the item by accepting it. That utterance is contradiction that Cucuk Lampah has a smoking habit. 
Datum 6 (00:01:09-00:01:25)

Context : Cucuk Lampah greet Pak Lurah Prancang Kulon village who comes in wedding ceremony to intend for asking job

Cucuk Lampah : Mbah Lurah selamat siang. Sehat selalu ta nggih?

Pambiwara $\quad$ : Sehat

(Healthy)

Cucuk Lampah : Suran (Sasi Sura) wayangan neh.

(Suran is a wayang performance again)

Pambiwara : Halah-halah padimu ben katut. Ra sah mbok takoni, engko lak diwehi mbah Lurah

(Halah halah you would be participant. Do not ask. Later, is given by mbah Lurah)

That utterances takes after Cucuk Lampah knows that pak Lurah comes in wedding ceremony. Cucuk Lampah requests that he could be participant in a wayang performance in Prancang Kulon village during Sura. The utterance "Suran is a wayang performance again" indirectly means for asking or offering which aims to benefit himself as well as getting job.

\section{c. Violating in Approbation maxim}

\section{Datum 1 (00:00:05-00:00:18)}

Context : Cucuk Lampah mocks to the artists of campur sari Sekti Laras Irama group which consists of elderly fathers and mothers. Cucuk Lampah has known them as campur sari artists.

$\begin{array}{ll}\text { Cucuk Lampah } & \text { : Sekti Laras Irama } \\ \text { Pambiwara } & \text { : Ho'o } \\ \text { Cucuk Lampah } & \text { : Alhamdulillah } \\ \text { Pambiwara } & \text { : Senimane sek mudo sedoyo } \\ & \text { (The artist are still young) }\end{array}$

Cucuk Lampah : Omongo mudo piye?. Wis poel kabeh

(What do you say young?.They all are old)

Cucuk Lampah introduces the group of campur sari Sekti Laras Irama to the guest invitation. However, Cucuk Lampah also ridicules by unrespecting other people who are older. Namely, the artists of campur sari are from that group. The ridicule is shown in the utterance "They all are old" which is stated directly. It is indicates the existence of violatong in approbation maxim.

Datum 14 (00:02:19-00:02:40)

Context : Cucuk Lampah asks about the song which is sung by Dewi when kirab Kanarendran is led by Cucuk Lampah.

Cucuk Lampah : Dewi yoh. Lagune mau opo?. Sambel Kemangi (Yes Dewi. What is song?. Sambel Kemangi)

Pambiwara : Panggah (Just keeping)

Cucuk Lampah : Layahe uombo (The mortar is wide)

Pambiwara : Opo we eruh? 


$\begin{array}{ll} & \begin{array}{l}\text { (Do you know?) } \\ \text { Cucuk Lampah }\end{array} \\ & \text { : Eruh aku } \\ & \text { (I know) } \\ \text { Pambiwara } & \text { : Kemeruh we ki } \\ & \text { (You know-it-all) } \\ \text { Cucuk Lampah } & \text { : Layahe Dewi ombo ireng } \\ & \text { (Dewi's mortar is black wide) } \\ \text { Pambiwara } & \text { : Cangkemu } \\ & \text { (Keep your mouth shut) }\end{array}$

Cucuk Lampah talks about a song in kirab Kanarendran time which act as the leader when the brides move towards the stage (pelaminan) in front of the guest invitation. At the time, Cucuk Lampah sings a song title "Sambal Kemangi" which is related to Dewi. In that utterance "The mortar is black wide" refers to a ridicule to Dewi and maximizes unrespect for women who has to be mother. "black wide" contanins female genital to bring up humor. Cucuk Lampah and Dewi are known as fellow artist.

\section{d. Violating of Modesty Maxim}

Datum 8 (00:01:26-00:01:36)

Context : Cucuk Lampah offers to join a wayang performance that holds in Sura month to the chief in Pragak village, and states in his prayer that the artist singer from Pragak village has many offers because of this.

Pambiwara : Halah-halah padimu ben katut. Rasah mbok takoni, engko lek diwehi mbah Lurah

(Halah halah you would be participant. Do not ask. Later, is given by the chief)

Cucuk Lampah :Nyatane bareng wayangan dirok prawan Pragak payu terus ta?

(In fact at the same time the wayangan performance is surrounded by girls who are from Pragak. Keep selling right?)

Pambiwara : Ora kok amarga wayangan payune kok yo

Cucuk Lampah : Dungoku ki kinabulan

(It is not because of a wayangan performance for the best-selling)

(My prayer is always granted)

The utterance of datum 8 shows that Cucuk Lampah does his own respect and expresses overconfidence feeling that his prayer is answered. However, in contradiction Pambiwara speculates that it is not only the wayang performance but also at the other events the singer could perform. So, the utterance in datum 8 shows violating of modesty maxim for respect towards Cucuk Lampah itself.

\section{e. Violating in Agreement Maxim}

Datum 25 (00:07:01-00:07:26)

Context : Cucuk Lampah judges one of Domas who has slim body, but she dances more active than the others. Cucuk Lampah does not know that the Domas is junior high school.

Dewi (Singer) : Iki loh sing iki lo 


\author{
(This is this one) \\ Cucuk Lampah : Kecil-kecil cabe rawit \\ (Smalls but brave) \\ Dewi (Singer) : Nerti aku kok yo \\ ( I know it) \\ Cucuk Lampah : He piye mas?, bocahe nek cilik malah briyel besuk anak'e \\ (He how mas?. A person who has slim body, tomorrow has a lots of \\ children) \\ Guests Invitation : loro loro \\ (Two two) \\ Cucuk Lampah : Loro yo. Cocok AI (Angka Ikut) engko yo loro tok \\ Kene jek usum ta?. Hayo rasah tuku togel \\ (Two. Matches AI (numbers join) later only two. Here is still \\ available. Come on, do not buy lottery)
}

In datum 25, there is violating in agreement maxim because Cucuk Lampah does not maximize agreement between the intentions of audience's utterances with himself. The utterances are spoken by audience "two two" refers to amount children who are said earlier by Cucuk Lampah as follow: "A person who has slim body, tomorrow has a lots of children". However, Cucuk Lampah replies with "Two. Matches AI (numbers join) later only two" that means the number prediction will come out in lottery games.

\title{
f. Violating of Sympaty Maxim
}

Cucuk Datum 44 (00:18:33-00:18:51)

Context : Cucuk Lampah mocks the kenong player namely the old man who does not have teeth

Cucuk Lampah : Dan juga Sekti Laras Irama tanggapane luaris (And also Sekti Laras Irama performance is in demand)

Pambiwara : Iki tanggepane adoh adoh

Cucuk Lampah : He'e (The show is far away)

Pambiwara : Adoh adoh

(Far away)

Cucuk Lampah : Berarti neng Nganjuk (It means in Nganjuk)

Pambiwara : Ora ngono (That is not)

Cucuk Lampah : Kertosono

Pambiwara : Adoh let te, adoh let te (it's far distance, it's far distance)

Cucuk Lampah : Bar tanggal 1 tanggal 30. Andengmu ki lo (After the $1^{\text {st }}$ is the $30^{\text {th }}$. Next to you)

Pambiwara :He'e

Lampah : Tanggapan telung dino ditukokne untu ora pas, la kleru untune rondo dipesen.

( Buying teeth because of the three-day show is not appropriate, instead one of the widow's teeth are orderedt) 
The datum above shows that Cucuk Lampah does violating in sympaty maxim. It can be unmaximize sympathy to the old man who plays kenong and has not teeth yet. In wedding season, group campur sari Sekti Laras Irama has increased many responses and incomes. Cucuk Lampah teases Kenong player with maximize no sympathy for his teeth. And he does not install the new teeth.

\section{CONCLUSION}

Based on analysis result of the data above. It can be concluded that violating politeness principle are found in Cucuk Lampah's untterances for creating humor in wedding ceremonial in Magetan regency. Cucuk Lampah does politeness principle consciously even unconsciously as means of establishment setup and punch. 44 data are found in Cucuk Lampah's utterances, the number of percentages as follow: Tact maxim 37\%, Generosity maxim 9\%, Approbation maxim 23\%, Modesty maxim 2\%, Agreement maxim 27\%, and Sympathy maxim 2\%. The violating of conversational maxims in carrying out interpersonal rheotoric or violating politeness principle become one of arising conversation as humor discussion. This form of violating causes a funny effect to listener.

\section{References}

[1] Dwiyasmono, "Subamanggala dalam Upacara Perkawinan Adat Surakarta: Refleksi Sosok Pemimpin Melali Perspektif Budaya," Jurnal Seni Budaya Mudra., vol. 26, no.2, pp. 10-16, 2009.

[2] Mulyana, “"'Struktur, Estetika, dan Peruahan Konteks dalam Wacana Pidato Upacara Perkawinan Masyarakat Jawa," LITERA, vol. 10, no. 2, pp.126-134, 2011.

[3] S. Wuri, “Aspek Linguistik dan Sosiokultural di dalam Humor, " PELLBA 5, 1992.

[4] Sudaryanto, "Metode dan Aneka Teknik Analisis Bahasa," Sanata Dharma University Press, 2015.

[5] Sumarlam, S. Pamungkas, and R. Susanti, "Pemahaman dan Kajian Prgamatik,"Surakarta, Bukukatta,2017.

[6] Widjaja, “Komunikasi dan Hubungan Masyarakat, “ Jakarta, Bumi, 1993.

[7] I. D. P. Wijana, “Kartun: Studi Tentang Permainan Bahasa,” Yogyakarta, Ombak, 2004.

[8] I. D. P. Wijana, \& Rohmadi, "Analisis Wacana Pragmatik," Surakarta, Mata Padi Presindo, 2009. 